\title{
RETHINKING DiASPORA
}

\section{Transforming Cultures eJ ournal, \\ Vol. 3 No 1, February 2008 \\ http:// epress.lib.uts.edu.au/journals/TfC}

\section{Anjali Gera Roy ${ }^{1}$}

Diaspora, a term used to refer to the dispersal of Jewish people across the world, now encompasses any deterritorialized or transnational population that lives in a land different from that of its origin and maintains links with the homeland (Sheffer 1986). Despite the recognition of diasporic contribution to the construction of national narratives, regional alliances and globalized political economies in recent years, diaspora remains under-theorized as a concept. Privileging race and ethnicity in the classification of diasporic groups based on the Jewish model, older definitions of diaspora tended to focus on migrations forced by religious and ethnic persecution overlooking both socio-economic factors compelling mobility and voluntary movements. As a result, the negative meanings of diasporas, characterized by exile, victimization, alienation and loss, dominated the understanding of diasporas while the positive saga of movement impelled by the desire for mobility, knowledge and adventure remained unexplored. The limited concern of these definitions with experiences of forced displacement, dispersal and exile also prevented an engagement with the meta-discourse of human migration and mobility to which diasporas belong.

In the last few decades, a serious attempt has been made to study the phenomenon in considerable depth and to offer more encompassing definitions (Sheffer 1986, Safran 1991, Clifford 1994). While these definitions differ in details, they agree on the critical components in diaspora that include a history of dispersal, the myth of a homeland, alienation in the host country and the desire for return and are governed by 'the place of origin' thesis (Shuval 2000). Diasporas have invariably been examined in relation to their similarity and difference from an originary homeland and relegated to derivativeness and secondariness. The place of origin has proved to be extremely problematic for two reasons - the difficulty of fixing the home as a category and the

\footnotetext{
${ }^{1}$ Anjali Gera Roy is Professor in the Department of Humanities and Social Sciences at the Indian Institute of Technology, Kharagpur, West Bengal.
} 
complex relationship between diasporas and the place of origin. Typologies invented to classify diasporas add to the confusion because of the diversity of variables- religion, race, region, nation, ethnicity, language (Cohen 1997). New studies have modified conventional understandings of diasporas by privileging experience, body and imagination in the constitution of diasporas that demystifies and complicates the place of origin myth, by constituting the homeland itself through the diaspora, by calling attention to 'the double-time' of the diasporas and by celebrating migratory experience in the discourse of hybridity and in-betweenness (Axel 2002, Chambers 1994) . ${ }^{2}$ The studies offer a way of reconceptualizing diasporas as a deterritorialized community disengaged from spatiality whether it is defined as a place of origin, continent, nation or region. ${ }^{3}$ These new imaginings of the self and community have weakened the link between space, place and identity noted in 'rooted' self-definitions and privileged hybridity, migrancy and in-betweenness that interrogate essentialist notions of identity linked to race, nation, language, religion or ethnicity. More recent theories have both extended and critiqued much of the earlier work, which had assumed homogeneous diasporas and identities defined territorially (Cohen 1997, Mishra 2006). Reflecting the movement in these studies to critique earlier studies of diaspora, this essay takes three fragments of the "Indian" diaspora, the imperial-mixed race Anglo-Indian, the nationaltechnocratic IITian, and the ethno-territorial Sikh to explore their differences along the axes of purity, home and nation. ${ }^{4}$ It also demonstrates how their internal identity is constructed from a range of diverse often unacknowledged components, and then changes over time, depending on the historical circumstances the group faces both at homeland of origin and their new home.

The first to implicate diaspora in the discourse of colonialism, Bill Ashcroft, Gareth Griffiths and Helen Tiffin, included both European settlers and colonized who traveled in the service of the Empire in their definition of diaspora (2000). The two colonial

\footnotetext{
${ }^{2}$ Homi Bhabha, Vijay Mishra, Paul Gilroy, Stuart Hall are among the many cultural critics whose theoretical constructs appear to be predicated on diasporas in particular. With the publication of Ian Chambers's book a new trend is visible in diaspora studies.

${ }^{3}$ Arjun Appadurai, for instance, has attributed the excessive diasporic involvement with the politics of the homeland to their fomentation of fundamentalist movements in the homeland. Brian Keith Axel corroborates this argument by providing the example of the Sikh diaspora, which has constituted the place of origin, namely Khalistan.

${ }^{4}$ IITians are graduates of the premier Indian Institutes of Technology, which have earned a global reputation for academic excellence. IIT alumni, who have distinguished themselves in various fields and are dispersed all over the world, form strong bonds during the years they spend at IIT, which they retain irrespective of where they might move.
} 
diasporas I shall engage with - the Anglo-Indian and the Sikh - complicate the binary division underlying their model. While Anglo-Indians could be said to be produced through the European in-migration to the colonies, the out-migration of their descendants after the end of the British rule, racial discrimination and the consequent construction of India as home interrogates the meanings of home, belonging and identity. Similarly, despite race being the dominant marker of Anglo-Indian identity, it cannot be theorized through the rhetoric of blackness put forward by Hall and Gilroy because of its intersection with religion in the proselytizing Christian missions. On the other hand, the Sikh diaspora, in which religion serves as the strongest element of selfconstitution, cannot be read as a 'pure' sacral discourse because of its contamination by the economic motif. Yet the Sikh diaspora is not a simple labour diaspora such as the girmitya or the slave because it was essentially produced by the movement of free migrants including those of war veterans. Though colonialism might have been the imperative for Sikh migration, it is religion that accounts for greater cultural retention noted among Sikhs. The movement of these two colonial diasporas also demands a diachronic perspective because the different waves of Sikh and Anglo-Indian migration reveal a variety of migration patterns. In their final stage, the migrations of Sikh and Anglo-Indian professionals have a lot more in common with those of skilled professionals- the IITians. The IITians, which refers to graduates of IIT, is used here to denote alumni of the prestigious Indian Institutes of Technology, a globally acclaimed institution in the field of technical education, who occupy the highest positions in business, industry and academia in India and abroad. The IITians who display a strong bonding and look upon the alma mater as home may be viewed as a new highly skilled postcolonial Indian diaspora, which may be contrasted with two colonial diasporas.

Among the diasporas I shall examine, the post-1984 mobilization of a sacral Sikh identity approximates to the Jewish model particularly in its invocation of 'the myth of purity' in the imagining of the Khalsa ('the pure') and Khalistan ('the land of the pure'). ${ }^{5}$ But the first wave of migration from Punjab beginning in the middle of the nineteenth century when Punjabi freeworkers were recruited to help in the construction of the railway network in East Africa would fall in both imperial and labour diasporas in Cohen’s typology.(1997 x-xi) However, even Sikh historians such as W H McLeod

\footnotetext{
${ }^{5} 1984$ is considered a crucial year in Sikh history when the Indian army raided the Golden Temple at Amritsar to flush out militants led by Jarnail Singh Bhindranwale. This desecration of the Sikh place of worship enraged the Sikh community and alienated it from the Hindus.
} 
have been wary of applying the term Sikh to this wave not only because migrants included Hindus and Muslims but also because of the absence of 'clear cut normative identities in Punjabi villages at the turn of the century' (1989). While religious difference had been central to Sikh self-definition as in the construction of Sikhs as a warrior sect, the privileging of the Khalsa and the militant Sikh imago over other narratives of Sikh identity appears to be a post-1984 phenomenon. Though a separatist Sikh discourse was beginning to be formulated at the end of the nineteenth century, three recent events - the raid of the Sikh shrine the Golden Temple in Amritsar by the Indian Army, the assassination of the Indian Prime Minister Indira Gandhi by her Sikh bodyguards in October 1984 and the reprisal killing of innocent Sikhs following the incident - completely alienated the Sikh community from the nation and renewed the call for a separate Sikh nation Khalistan (the land of the pure). The decade of 'the Punjab problem' when Sikh militants resorted to violent methods to voice their demand for a separate nation also altered the perception of the Sikhs in the Indian imaginary. Dipankar Gupta has proposed a triadic framework of Hindus, Sikhs and the Indian nation state to "account for the self-images and the perceptions of reality that rival ascriptive groups propagate in periods of tension” (1997: 93). He draws on Lacanian insights to formulate the idea of a Sikh imago to show that the Hindu image of the Sikhs underwent modification from 'the reliable sword-arm of Hinduism' (Banga 1988: 244) to the 'hot-headed, murderous wrecker of the Indian nation-state' after 1984. He also points out that the militant Sikh imago that came into existence in contemporary Punjab was not quite the self-image that the Sikhs had of themselves in the past. Making a distinction between identities emerging in situations of ascriptive tension or 'imagos' from those formed in times of peace or 'cultural constitution', Gupta stresses the importance of 'a correlative space' to make us aware of "the dynamic character of cultural and ascriptive identities and how vulnerable they are to change” (1997: 94). I wish to point out that the mobilization of 'the purity myth' in post-1984 narratives of Sikh identity that draws parallels between the persecution of the Sikhs by the Indian state in the present and that by Muslim conquerors in the past subsumes the previous construction of Sikhs as 'the swords of the Hindus' during the Moghul period and 'the warrior race' in British imperialism. The strategic invocation of the pure Khalsa narrative of Sikhism after 1984 also illustrates the dynamic nature of Sikh identity and how it has been constantly changing over the centuries. 
These sacral imaginings of the Sikh diaspora in the post 1984 imagining of Khalistan in which the Sikh kaum is represented as being persecuted by a series of non-Sikh rulers including Moghul, British and Hindu display an amnesia to the imperialist and labour origins of Sikh migration in the British empire. ${ }^{6}$ Tracing the history of Sikh migration in colonialism, Joan M Jensen traces the fascinating passage of Sikhs from India when the British control over the distribution of land and the preferential recruitment of Sikhs in the British army made young Sikhs disperse to various parts of Africa, America and Australia while fighting for the Empire abroad (1988). Jensen's study attributes Sikh migrations to imperial politics in Punjab and argues that the Sikh emigrants were part of a larger Indian diaspora that "accompanied the development of British colonialism in India". This, in turn, was part of a still larger movement of migrants "loosened from their native lands in the late nineteenth and early twentieth centuries" by "the push of economic dislocation" and by "the pull of economic demands in industrializing countries” (1988: 9). Jensen makes a distinction between the free migrations from new areas such as Punjab during this period from the earlier phase of plantation migration that coincided with the abolition of slavery in 1834. But this free migration was compelled by the worsening of economic conditions in Punjab due to population explosion followed by droughts, famines, and severe epidemics when younger brothers were encouraged to migrate to prevent sub-division of family owned land. Migrations could be direct overseas movements in search of work or indirectly occasioned by enlistment in the army or in railroad construction (1988; 24-25). The Sikh diaspora, thus, is a product of the British Empire created through the British preferential recruitment of Sikhs in the army as one of 'the martial races' and the imperial intervention in the Punjabi economy through the Land Alienation Act of 1901. But Sikh free labour prevents one from lumping it together with other imperialist labour diasporas named by Cohen (1997).

Defying the Khalsa narrative of a unified 'pure' Sikh identity, Sikh identity is also internally differentiated by castes arranged according to their degree of purity. These caste identities posit alternative identarian narratives challenging the imagining of a homogeneous sacral community. Eleanor Nesbitt's ethnographic analyses of diverse Sikh groups in Britain conducted over several decades have uncovered strong caste

\footnotetext{
${ }^{6}$ For a discussion of the semantic distinction between panth and kaum, see McLeod. McLeod points out that Sikhs use the word panth or path not kaum the term for 'community' to define Sikhism. (Appendix 3) The formulation of a separatist Sikh discourse is predicated on this semantic difference.
} 
loyalties intersecting with alternative sectarian affiliations that complicate the imagining of a unified Sikh diasporic discourse (2000, 2004). Nesbitt's findings that inscribe a wide range of Sikh castes from the amritchakia or asal or pure Sikhs to those who merely adopt Sikh practices also position 'purity' inversely with migration. While Sikhism's rejection of the Hindu pollution complex might explain the greater Sikh mobility during colonialism, as Nesbitt notes, Sikh migration overseas was largely that of 'impure' majhabi (or dalit caste) rather than of the 'asal' Sikhs or the more strict adherents of Sikhism. The greater part of the Sikh diaspora consists of the 'lower' castes of skilled artisans, carpenters, blacksmiths and followers of less 'pure' Sikh sects. Sikhs from these lower castes were hired as free labourers and employed in the construction of the British Empire in other colonies. The relative 'impurity' of these castes might have to do with their being regarded as later converts embraced in the Sikh fold as disciples rather than asal or orthodox Sikhs. But the exclusion of the skilled lower castes by dominant landowning Jats is underwritten by both caste and racial superiority. ${ }^{7}$ The Jats are believed to be the descendants of Scythians and are spread over Punjab, Rajasthan, Haryana and Uttar Pradesh bringing their Sikh religious identity as well as Punjabi linguistic identity into conflict with caste identity.

In addition to sect and caste, regional difference, an important constituent in Sikh selfdefinition makes Sikh identity overlap with other Punjabi identities such as Hindu and Muslim. Since the Sikh homeland is invariably a small place, a village or a pind, loyalties to the region often supercede those to religion. The concept of the bhumbhai (brother by region) and dharambhai (brother by religion) outlined by Verne Dusenbury partially resolve the contradictory caste, sectarian and regional affiliations observed among Punjabis (1995). These conflicting loyalties to religion, sect, region and caste among Sikhs warn us against viewing the Sikh diaspora as a purely sacral diaspora. ${ }^{8}$ The spurt of conversions that accounts for the exponential rise in the Sikh population between 1901 and 1911 also attest to the fluidity of boundaries within Sikhs and

\footnotetext{
${ }^{7}$ McLeod defines Jats as 'a rural and agrarian community consisting largely of peasants and landlords (1999, p.10) known for their "impressive physique", "straightforward manner", "for a tremendous generosity, for an insistence upon the right to take vengeance, and for their sturdy attachment to land" (ibid., p.11) They are a pastoral people who migrated from Sind to Punjab via Multan and across the Jamna and became cultivators. The fact that the majority of Sikhs even today are Jats with a rural base who form the elite of the Punjab villages explains the Sikh panth's development along Jat cultural patterns.

${ }^{8}$ While presenting her fieldwork on Doaba Sikhs, Kaur warns against ignoring the differences of Jat Sikhs belonging to the three Punjab regions of Malwa, Majha and Doaba.
} 
between Hindus and Sikhs and warn against the imagining of a purely sacral Sikh narrative. $^{9}$

As a colonial migration facilitated by caste impurity that plays a central part in the production of a transnational pure Sikh narrative after 1984, the Sikh diasporic formation also problematizes the contemporary celebratory narratives of hybridity and assimilation dominating diaspora studies through its strong cultural retention. This is perhaps due to the fact that the period of the intensive international migration (18801920) was also a period "when a new cultural elite of neo-orthodox Sikhs, in response to British colonial and Christian presence in Punjabi were in the process of subsuming a variety of Sikh subtraditions ... under a monolithic, codified, and refined religion” (Oberoi 1988; 149). This formalized identity based on 'the myth of purity' produced during this period accounts for the stronger cultural retention noted among Sikh migrants despite the Sikhs being one of the oldest Indian diasporas with a history of migration beginning almost a century ago. As in other sacral diasporas, geographical difference is subsumed by religious continuity and facilitated through the newly devised sacral script gurmukhi. Apart from the compulsion to read gurmukhi so as to be able to follow the Sikh scripture, religious injunctions pertaining to the five Ks and other religious taboos pertaining to food, drink and observances make the Sikhs the most visible diaspora. ${ }^{10}$ Except for the years when immigration laws did not permit Sikhs to return home or bring back families, Sikhs have been known to retain their links with their home village through frequent visits, marriage and investment in land and property as elaborated by Roger Ballard with reference to Sikhs migrants to Britain (in Parekh et al 2003). In particular, the practice of rishte or finding a partner for one's children in the natal village that Ballard found among UK Sikhs ensured cultural continuity among Sikhs in Australia and Canada as well. This explains why Sikhs who have left their land of origin almost half a century ago are still able to communicate with one other and their kin in the homeland. The Woolgoolga Sikhs in Australia, the Vancouver Sikhs in British Columbia, the Yuba Sikhs in California, in addition to the UK Sikhs, present

\footnotetext{
${ }^{9}$ McLeod argues that Sikhs are not necessarily Khalsa. He also cites census figures to illustrate the shifting boundaries between Hindus and Sikhs and how Hindus, to take advantage of the preferential treatment of Sikhs in the British army, passed off as Sikhs thus accounting for the exponential increase in Sikh population. The 1881 census in Punjab (including Delhi) shows Sikhs as 17,06,909 out of which $66 \%$ were Jats. By the 1937 census, they had increased to 40,71,624.

${ }^{10}$ Sikhs are required to wear five objects on their body - kes (hair), kangha (comb), kirpan (sword), kada (iron bracelet), and kachcha (long shorts), which are called the five Ks.
} 
unique examples of Punjabi cultural continuity. Traditional Sikh networks and Sikh institutions such as gurdwaras have also played a dominant role in cultural retention in the past through religious instruction that doubles as cultural training.

Sutured temporarily due to legal measures, Sikh ties with the homeland and other dispersed Sikhs have been intensified by the advent of new communication and travel technologies facilitating ease and frequency of movement and contact. ${ }^{11}$ Places of Sikh dispersal and settlement have formed a Sikh nation dispersed geographically but connected by language, culture and religion. While new technologies have facilitated the demolition of geographical and physical boundaries, Sikh identifications after 1984 display the thickening of old boundaries like caste, sect and region and construction of new boundaries based on class, education and profession. Therefore, the emancipatory narrative of transnationality emerging in recent debates on transnationalism has been reversed in the Sikh case with the rise in Sikh fundamentalism and return of old caste or regional loyalties. If new media and technologies were appropriated by fundamentalist Sikh elements in the articulation of the transnational separatist discourse of Khalistan, they also played an equally important role in fissuring Sikh identity along caste and sectarian lines.

In the demand for Khalistan, in which diaspora Sikhs played a leading role, may be witnessed the invention of a Sikh homeland in Punjab and the reconceptualization of an ethnoterritorial diaspora that has become the central problematic of Sikh studies. The dream of Khalistan, a nation without a territory that took shape in cyberspace, is predicated on the secession of a real territory though the modalities of secession might not have been clearly formulated. ${ }^{12}$ The Khalistani discourse that was renewed after

\footnotetext{
${ }^{11}$ The strength of these transnational networks in new electronic media such as the internet, satellite television in the construction a transnational Sikh community cannot be underestimated. The story of how these networks were mobilized by Sikh militant organizations in creating sympathy for their cause and the consequent rise of fundamentalism is well known. A transnational beauty contest conducted on satellite television recently strongly reflected the interconnectedness of Sikhs dispersed over different places. The first Miss World Panjaban contest organized by ETC Channel Panjabi had participants from Sikh settlements in India as well as overseas vying for the title. Initiated with the objective of inculcating Sikh cultural values globally, the criteria for selection were formulated in accordance with Punjabi culture and values. The participants had to impress their judges as much as by talent and beauty as embeddedness in Punjabi language and cultural values. The winner of the final contest held on $16^{\text {th }}$ December 2006 compered by a Sikh Canadian radio presenter Meera and sponsored by a Sikh Australian was Japji Khera from Australia.

${ }^{12}$ Refer to Vinay Lal's discussion of the Hindu cyber-diaspora and the rise of Hindu fundamentalism in his essay and the intervention of Hindu diaspora in homeland affairs that resembles the diasporic discourse of Khalistan formulated outside the Indian nation.
} 
1984 demonstrates that both the notion of identity and of nation are historically shaped by the needs of the community at a particular time. Dusenbury has located the emergence of this ethno-territorial Sikh discourse to the local politics of race, ethnicity and multiculturalism in countries like Canada, United States and United Kingdom predicated on a modernist assumption of 'a place of origin' (1995: 32). He explains that the appeal of Khalistan to diaspora Sikhs 'may be the creation of a publicly recognized "country of origin" from which Sikhs may legitimately make claim to their own political voice and to the perquisites of public support for cultural diversity' in their countries of residence (ibid. 32-33). Arjun Appadurai confirms that the politics of homeland catalyzed the renewal of the separatist demand. His view of Khalistan as a post-Westphalian transnational formation that suggests a way of thinking community in isolation from the nation is ante-dated by Brian Keith Axel's thesis about the centrality of the body in Sikh self-constitution from the time of the Khalsa and the making of the amritdhari body (2002). The Sikh historian Harjot Oberoi, however, exposes the limitations of the post-1984 theorizations of Sikh history that accentuate Sikh difference by privileging the Khalistan narrative over other narratives of Sikh history. In contrast to Appadurai and Axel, who locate Sikh identity in a post-national geography, Oberoi disengages Sikh identities from national formations by relocating Sikh history in prenational porous and fluid boundaries (1994). As the Sikh migration predated the making of the nation by nearly a century, it is not the nation but memories of Oberoi's 'village' identities where boundaries may be porous and intersect at the level of everyday life, which live on in diasporic memory and are strengthened by the connectivity enabled by advanced travel and communication technologies. Dusenbury, on the other hand, maintains that the home, though it also denotes a small place, a village or town in Punjab, primarily signifies the Sikh places of worship scattered over the Indian and Pakistani nation state. Although displaced or urban Sikhs have lost their roots in Punjab, the 'homeland' as Sikh shrines appears to live in the memory as a self-contained entity independent of the nation ${ }^{13}$ (1995). Brian Keith Axel's thesis about the centrality of the body in Sikh self-constitution from the time of the Khalsa and the making of the amritdhari body also decouples identity from spatiality and the nation (2002). While Khalistan may be regarded as a post-Westphalian transnational formation that suggests

\footnotetext{
${ }^{13}$ I would like to thank Viney Kirpal, a practicing Sikh, for distinguishing between rural Sikh landowners with strong roots in Punjabi villages and urban and displaced Sikhs without territory in whose imagination Sikh religious places like the Nankana Saab, the Bangla Saab substitute for the homeland. Brian Keith Axel makes the same point in his book.
} 
a way of thinking community in isolation from the nation, its appeal to purity also signals a return of tribes that appears anachronistic in the postmodern celebration of hybridity.

If the Sikh invocation of purity appears to be out of place in the contemporary hybrid landscape, the celebration of mixed race in this new rhetoric does not overwrite the old racism of miscegenation through which Anglo-Indians have been conventionally viewed. Anglo-Indians, used to define Indians of mixed Indian and European ancestry, is a category directly implicated in colonialism. The term Anglo-Indian came to be used in the second half of the 19th century by people of mixed descent, a term which was then used to refer to Europeans living permanently in India and included those who were earlier classified as Eurasians. Subsequently Article 366(2) of the Indian Constitution provided a more formal definition: "An Anglo-Indian means a person whose Father or any of whose other male progenitors in the male line is or was of European descent, but who is domiciled within the territory of India and is or was born within such territory of parents habitually resident therein and not established there for temporary purposes only." Anglo-Indian history predates British imperialism imbricated as it is with several waves of European invasions such as that of the Portuguese, the French and the British. The Anglo-Indian exodus to various parts of the British Empire began following Indian Independence in 1947 but a large number continued to stay behind in India for various reasons.

Race has always been an important category in Anglo-Indian identification that intersects with that of caste. While their mixed race status earned Anglo-Indians entitlements and privileges denied to brown skinned Indians in the imperial state, the discourse of miscegenation was simultaneously invoked to stigmatize them as inferior to domiciled Europeans. At the same time, ancient Hindu fear of miscegenation forbidding intermarriage with foreigners translated in the representation of AngloIndians as mlechcha or unclean. The purity fetish that was appropriated in the constitution of the 'pure' Sikh diaspora resulted in the ascription of Anglo-Indians as 'impure'. Though the Anglo-Indian diaspora privileges race as a category in its selfconstitution, as a mixed race diaspora it cannot comfortably evoke racial essence as in discourses of blackness and whiteness without bringing into prominence its own neither/nor status. Adrian Carton's emphasis on “the need to 'historicize' the notion of 
hybridity by placing the question of 'mixing' in situational contexts that not only reclaim cultural specificity but also illuminate the differing constructions of cultural difference across space, time and imperial location” is particularly relevant in examining Anglo-Indian diasporas (2007, p.146). Kathryne Mitchell's view on "the disingenuous move of the concept of hybridity" as inferring a universalized "third space' that is 'beyond the situated practices of place and the lived experience of history' explains why the celebratory narratives of hybridity in the West have not altered the conditions of Anglo-Indians in India (Mitchell 1997: 534). The discourse of miscegenation against which the Anglo-Indian subjectivity was traditionally viewed located the Anglo-Indians uncomfortably in a zone where they were confronted with white racism on one hand and the Indian pollution complex on the other (Mills 1996). The pollution complex is a late Vedic development in Indian religion that misinterprets hints in early Vedic texts to arrange castes in a hierarchy based on the myth of purity. While practices such as untouchability were abolished through legal forms after Independence, the pollution complex that forbids the intermixing, interdining and intermarriage of higher castes with lower castes, particularly those deemed untouchable, still regulates marriage rules. ${ }^{14}$

Anglo-Indian history is one of transforming in-betweenness, neither European nor Indian, into a marker of belonging through Anglo-Indian self-constitution as an exclusive 'European' community in separation from 'native' populations. While its social exclusion supported by privileges accorded it by the imperial state provided it an exclusive status before Independence, its mixed-race identity became a cause for stigmatization once privileges were withdrawn. The post-colonial privileging and valorization of hybridity does not seem to have altered the perception of Anglo-Indians in India whose identification with the white ruling class makes them outsiders in India but their attempt to assimilate into white culture through migration proves equally problematic.

The racial understanding of Anglo-Indian diaspora is complicated in the Indian context with the imbrications of colour with religion and culture in the denial of belonging to

\footnotetext{
${ }^{14}$ The example of a highly educated Hindu Brahmin couple who disowned its son for marrying an AngloIndian girl comes to my mind. The couple married in the early nineties and the Brahmin couple accepted the daughter in law literally when they were on their death bed more than a decade later in a replay of the 70s film Julie. Despite the anguish this caused the Hindu and Anglo-Indian families, Indian social norms have not kept pace with legislative measures that forbid discrimination on any grounds.
} 
the mixed race groups formed by the liaison of Europeans - Portuguese, French and English - with Indians. Notwithstanding the privileges enjoyed by Anglo-Indians in the British Raj and their exoticisation in popular cultural images, the social acceptance of Anglo-Indians was underlined by the miscegenation discourse. While this narrative of miscegenation has been framed against white purity in mixed-race discourse emerging in the West, it has not been discussed in relation to the Hindu pollution complex and racial purity. The Hindu debate on mixed race must engage with Vedic strictures against the 'wrongful union' between the arya and the anarya and the denunciation of the foreigner as mlechcha or unclean. ${ }^{15}$ An ambiguity prevails in the definition of the arya and anarya in the Vedic texts with arya being used both to distinguish light skinned Aryans from darker skinned and to denote those who follow the arya way of life. However, marriage between arya and anarya was strictly forbidden and the offsprings of such unions were categorized as lower castes. Few texts, except the problems of an Anglo-Indian Hindu romance in a Malayalam/Hindi commercial film in the 70s and Aparna Sen's moving portrayal of an Anglo-Indian schoolteacher in the 80s, have engaged with the problematic location of the Anglo-Indian community within India. As in the 70s film Julie, the relations between Anglo-Indians and other communities continue to be regulated, at least in the domain of marriage, by ancient Hindu strictures against intermarriage with ‘unclean’ castes.

One of the reasons for the absence of the impact of the privileged discourse of hybridity on the lived experience of mixed race groups is the intersection of race with class and skills. While class was inseparable from race during the British rule, the withdrawl of racial preference after Independence allowed only Anglo-Indians with high skills or university degrees to retain economic superiority relegating those with low skills to lower economic status and class. Education played an important role in the AngloIndian readjustment in independent Indian society. While those with university degrees and professional qualifications were able to maintain parity with other Indian ethnicities and even afford their pre-independent status, unqualified Anglo-Indians were reduced to a life of penury and social exclusion. Anglo-Indians constitute a sizeable postindependence Indian diaspora overseas with a large number of Anglo Indians deciding to migrate to UK or Australia in 1947, which continued over the next six decades so that

\footnotetext{
${ }^{15}$ The polarizations arya and anarya employed in Vedic texts refer to Aryans and both indigenes and foreigners respectively.
} 
Anglo-Indian towns in India are ghost towns with the young having migrated leaving behind only the elderly. A large number of Anglo-Indians were also forced to migrate to urban centers within India due to the withdrawal of preferential placement in government and other sectors and such occupations where fluency in English was an asset. With skin colour not guaranteeing privileges after Independence, the outmigration of low-skilled Anglo-Indians to different parts of the Empire in the second stage of migration in the 60s came to resemble those of other labour diasporas.

Unlike Sikh migrants who were forced to leave homes for economic reasons and continued to retain links with home for several generations, Anglo-Indians voluntarily migrated because of not feeling at home in independent India and their children and grandchildren had no emotional or psychological links with India. It was the discrimination by host countries that has produced in Anglo-Indians, particularly the elderly, the desire for a home. Unlike the Sikhs, Anglo-Indians dispersed across the country are unable to fix on a particular homeland such as Punjab but return to the memories of the town or city from which they had migrated. Even though it was a home in which they were regarded as outsiders, albeit privileged ones once upon a time, the direct experience of white racism in places of settlement explains the Anglo-Indian nostalgia for the Indian home. ${ }^{16}$ The experience of being an outsider in Europe and Australia either compels a stronger bonding with the Indian home through a greater assimilation in Indian cultural practices or retreat into a private world of misery, loneliness and alcohol. Unlike the Sikh homeland that is located in a specific region, the Anglo-Indian diaspora locates home in imperial institutional networks particularly the railways in which the majority of Anglo-Indians were employed. The Anglo-Indian homeland is a network of railway towns in which families might have lived at different points of time. Railway colonies in these towns were dominated by an exclusive AngloIndian culture different from those of domiciled Europeans as well as that of surrounding Indian populations. These colonies, it must be pointed out, live on only in Anglo-Indian memories and photographs with the disappearance of the Anglo-Indian way of life through the exodus of their Anglo-Indian occupants. Unlike the Sikh diaspora that reinvented itself as an ethnoterriorial diaspora by inventing a home in Punjab, Anglo-Indian identarian narratives must return to an imaginary imperial past.

\footnotetext{
${ }^{16}$ Based on interviews conducted with Anglo-Indian families in Kharagpur and Sydney between October to December 2006.
} 
It is in the light of the experienced reality of Anglo-Indian groups that the privileged location of the post-colonial discourse of migrancy and hybridity becomes foregrounded. The valorization of in-betweenness and hybridity as an advantageous position and the double vision it provides must be juxtaposed against the lived reality of in-betweenness that Anglo-Indians as a community epitomize. The post-colonial valorization of hybridity and migrancy does not appear to have affected the perception of the Anglo-Indian diaspora in the Indian imaginary proving the allegation about postcolonialism being an elite discourse framed by postcolonial intellectuals in the diaspora (Dirlik 1997). The opposition between the discursive recognition of inbetweenness and hybridity and the material conditions of in-between groups brings out the distance between theory and praxis. The question that becomes important in the case of the Anglo-Indian diaspora, therefore, is whether the post-colonial discourse of hybridity can displace the older discourse of miscegenation within which mixed race groups have been traditionally examined. Will postcolonial theory herald a third space in which differences of race or colour will lead neither to exoticization nor stigmatization of in-between people? The Anglo-Indians' forced in betweenness makes them a paradigmatic example that may be used to interrogate the elitism of postcolonial theory.

As compared to these old low-skilled diasporas constructed by race, religion, ethnicity and gender, the IITians, a highly skilled professional diaspora, presents a new way of imagining community in relation to commonality of goals and interests converging on a national institution in which national identity is accretive rather than disjunctive with other self-definitions. Graduating from a haloed institution that was 'dedicated to the service of the nation' after Independence, it is surprising that IIT graduates should not only have become a globally recognizable brand but that their self constitution as IITians should subsume all other markers of belonging such as nation, language, religion or ethnicity. ${ }^{17}$ A special report on IITs in a leading Indian weekly Outlook to commemorate the golden anniversary of the institutions estimated that roughly half the undergraduates from the 7 IITs, that is between 1500 to 2000 young men and women,

\footnotetext{
${ }^{17}$ The words "Dedicated to the Service of the Nation" are inscribed on top of the entrance to the Main administrative building of the Indian Institute of Technology Kharagpur. It is ironic that the golden jubilee of this national institution set up by the first Indian Prime Minister Jawaharlal Nehru should have been celebrated in silicon valley.
} 
leave every year for studies abroad with US as the most preferred destination. There were about 25000 IITians in the US in 2000 with a combined worth of 30 billion dollars and 10 per cent of the startups between 1995 and 1998 in silicon valley were by IITians. The Real Brain Drain by the Director of IIT Mumbai revealed that 30.8 per cent of alumni who graduated from the institution during the period 1973-77 had settled abroad (1994). A 1989 study of IIT Madras B. Tech. graduates done by M.S. Ananth, K. Ganesh Babu and R. Natarajan for the Department of Science and Technology found that 26 per cent of them went abroad between 1964 and 1987. Similar figures may be cited for the other five IITs. While the IIT alumni overseas might comprise less than 1 percent of the Indian population, the dispersal of the IITians, their self perception as a separate community and the production of IIT as home qualifies them as a diaspora. Unlike Sanjay Srivastava who compiled an ethnographic study of the Doon School that provided a glimpse into the construction of an elite national subject through a public school, no IIT graduate has attempted a history of India's leading institution of science and technology. But three fictional works by IIT alumni - The IITians by Sandipan Deb, Five Point Someone by Chetan Bhagat and Anything for You, Madam - by Gaurav Ahuja have unveiled the rarefied world in a developing nation that is the Indian Institutes of Technology. Rukmini Bhaya Nair's Technobrat had provided the faculty side of the story several years ago - the IIT Undergraduate as s/he appears to those who have been enlisted in the responsibility of grooming the 'crème de le crème' of the Indian youth, as IITians are euphemistically named.

Other than the arrogance that stems from having passed one of the most difficult competitive examinations in the world, there are several reasons that contribute to the perception among IITians that they are a separate breed. ${ }^{18}$ Selective definitions of the IITian provided by alumni in response to a questionnaire circulated in October 2006 for this study below provide a glimpse into how IITians view themselves:

- High achiever, yet unassuming, intelligent, hardworking, honest and sincere.

- One who is fearless and can take tough challenges and risks.

- One who combines the skills learnt at IIT with his experiences to achieve.

\footnotetext{
${ }^{18}$ In 2002, 169,563 high school students appeared for the screening test of the Joint Entrance Exam (JEE) and 3,878 (approximately 2.3 per cent of the candidates who appeared for the screening test) were offered admission to various undergraduate courses in the participating institutes.
} 
- One seeking ultimate success and perfection in whatever he undertakes.

- Who keeps abreast of latest developments in order to retain self-confidence and self-dependence.

The IIT system seems to have been predicated on principles that challenge traditional markers of identity and belonging. As a meritocracy that constitutes its graduates as elites of the brain, the IITs inscribe a difference in essentialist state-centric, ethnolinguistic/ethno-regional or sectarian identifications. The sole criterion for joining the exclusive IITian club is the ability to solve complex problems in Physics, Chemistry and Maths in more specialized disciplines over the years. Alumni of the Institute concur that arrival in IIT was their first step out of old identity markers because residential requirement forced them into contact with individuals from other languages, regions, classes, castes, and religions. The subsuming of all difference to belonging to an institution are compelled, in my view, through the pressure that the IIT system places on young men and women away from home for the first time in their lives. It is these pressures generated in the IITs' highly competitive environment propped on relative marking, punishing class schedules, quizzes, tests, assignments combined with rare freedom that accounts for the lifelong bonding between fellow IITians. ${ }^{19}$ Some sample answers from IIT alumni explain what binds IITians as a community.

-Same type of 'Fundas',20

-Their common learning ground and thinking

-I find IITians bond immediately and get along very well with each other

-They have been thru the same 'grind'

-Common pursuit and life

Few institutions, academic or other, evoke the kind of nostalgia that life in IIT does. A post on the website of IIT Foundation reproduced below is representative of the strong emotions that IIT days produce in their alumni. The poem composed by an alumnus of IIT Kharagpur Apurva Kumar, which is an improvisation on a popular ghazal by Jagjit Singh on nostalgia for lost youth, has the IITian offering to exchange his degree, job,

\footnotetext{
${ }^{19}$ These answers were received in response to the question "Do you think IITians are a community? If so what binds them?” in a questionnaire circulated among IIT Kharagpur alumni in October 2006 for the purpose of this study.

${ }^{20}$ Fundas, IITian slang for fundamentals is a term with multiple significations ranging from fundamentals of science and engineering to those of life.
} 
and even his US visa in return for food in the Hall of Residence canteen and other popular 'hang-outs' in IIT Kharagpur (KGP to students).

General

Postings related to IIT Kharagpur only, please. No vulgarity and no personal attacks allowed.

Posted by y: apurva kumar (Mar 29, 2003)

Subject: dedicated to iit days Message:

Ye degree bhi lelo ye naukari bhi lelo Bhale chahe lelo mujhse US ka Visa...

(Take away my degree, my job And even my US visa!)

magar mujhe lautado hall ka canteen vo chedis ka tinku vo harry ka samosa...

(But return to me my Hall canteen

Chedis' 'tinku' and Harry’s samosa)

college ki sabse purani nishani vo chedi jise saare kehte the jaani... (The oldest memory of my college days

The one which all knew as my life)

wo chunu ke haathon ki sutta \& paan meethi

wo chupke se OP mein bheji hui chitthi...

(The 'sutta' made by Chunu and sweet pan

The letter secretly slipped through $\mathrm{OP})$

wo padhte hi chitthi dosa ka tilmilana

wo chehre ki laali vo aankhon ka gussa...

(Reading the letter, the DOSA's anger

The reddening of his face, and the anger in his eyes)

kadi dhup mein psych ho ke hall se nikalnaa wo project ki khatir guide ke pas bhatak na...

(Leaving the hall psyched at the height of noon

Sidling up to the guide for the sake of a project)

wo lecture mein dostonki proxy lagana

wo prof ko chidhana vo aeroplane udana..

(Proxying for friends in lectures

Teasing the Professor and flying paper planes)

wo submission ki ratonko jagna jagaana

wo viva ki khahani vo practical ka kissa....

(Staying awake on nights before submission

The story of the viva and the tale of the submission)

submission time B.C.Roy mein bimari ka bahana wo dusaron ke assignments ko apna banana...

(Malingering illness in BC Roy at submission time

Passing off others' assignments as one's own)

wo workshop and lab mein din raat pasina bahana... wo lab submission ke din topper ko patana

(Sweating day and night in the workshop and the lab 
(The restless atmosphere on the day of the exam

But the assurance of cheating, and faith in the one seated in front)

exanm main beetein wo lambisi ratein

wo doston se batein wo lambi si bhatein...

(Those long exam nights

Those chats with friends, those endless chats)

wo midsem main hamesha makhana, endsem phodne ka plan banana,

(Always messing up the mid sem

Finding out ways of 'cracking' the endsem)

wo endsem main bhi ch__ ke aana, wo "G" marna phir sab maya batana
Sucking up to the topper on the date of lab submission)

wo exam ke din ka bechain maahaul

par wo tipne ka vishvas samnewale ka bharosa...

wo library main bandi tapne jaana wo bandiyon ka yun hi bhao khana (Going to the library in search of females

And the airs the females put on)

wo farewell ke din pi ke rona wo 2nd years ko phir funde pilana (Those tearful hangovers on farewell days

Those funda talks with $2^{\text {nd }}$ years)

bhulaaye nahi bhul sakta hain koi, wo IIT-KGP ke din, wo baaten purani

(Hard as I may try I cannot forget Those days in IIIT and those old stories)

www.iitfoundation.org/msgboard/sh owmsglist.
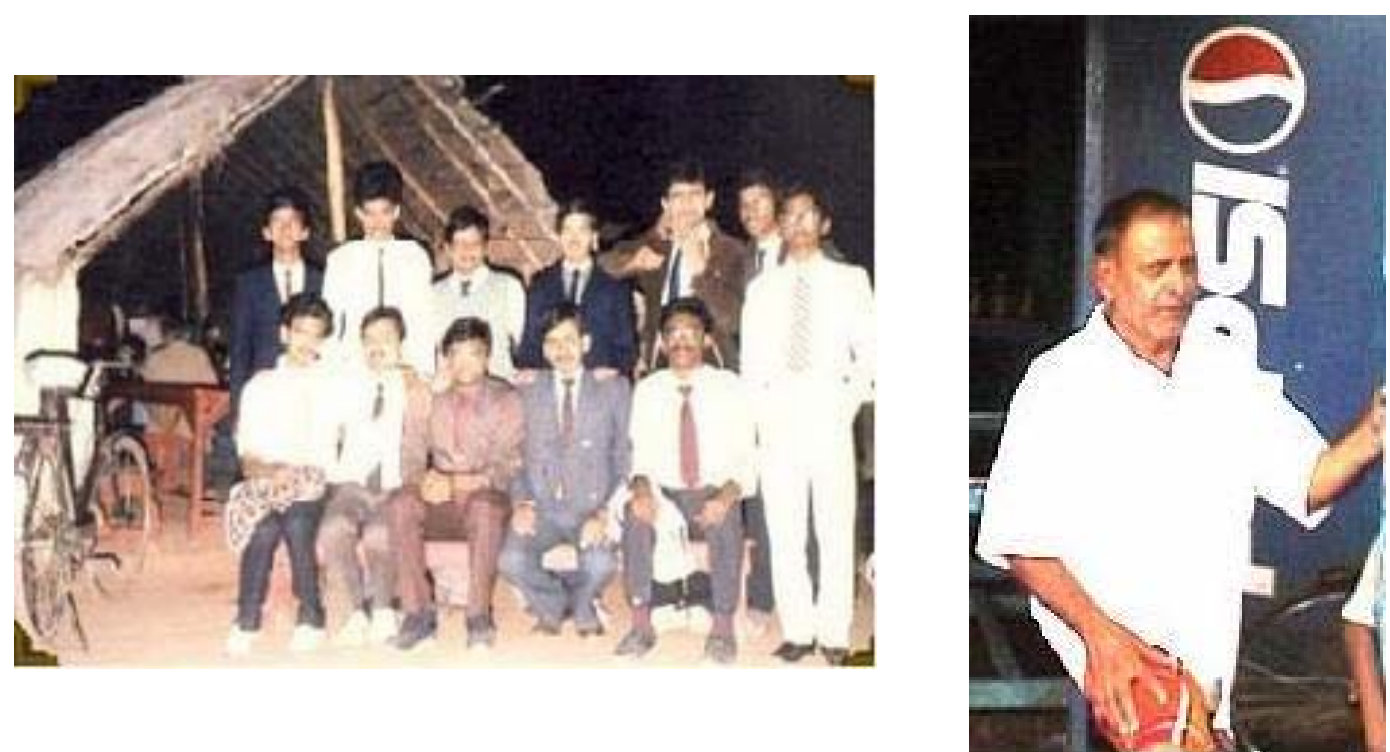

KGPians outside Chedis and Mr Anwar alias “Chedi”, The Scholar's Avenue. 18/8/05 Foundation Day Special 
March 30th, 2006, 04:09 PM

Ever seen of an eating joint that runs 24 hours a day,7 days week for the whole year.

CHHEDI'S is such a place-just outside the IIT Kharagpur campus. It is just a roadside shack serving snacks, you won't even dream of entering even if you are dying of hunger. But generations of KGPians have grown up on Chhedi's. As it said that "chedi's is an institution in itself".

As a community formed through abilities and interests, the IITian diaspora provides an example of the neo-tribes of postmodernism that converge on social spaces. A ramshackle teashop outside the gate of IIT Kharagpur offers an illuminating example of social spaces that might acquire almost sacrosanct status for members of neo-tribes. ${ }^{21}$ Chedis, named after its owner by students due to the "chhed" or hole in his nose, has been the favourite haunt of generations of IIT Kharagpur students for nearly half a century. A dark space with long wooden benches and log tables serving local gastronomic delights with such romantic names as Tinku, Mohile and the Jassi Burger has been immortalized by KGPians or students of IIT Kharagpur by naming a residential colony in the US after the tea-shop owner. Chedis is the first stop on the pilgrimage route of billionaire alumni Vinod Gupta on his annual visits to IIT Kharagpur who borrows an old classmate's rickety bicycle to race up to Chedis for tea and bun-omlette. The KGP alumni have also named their website chedis. The shop has changed locations three times over the years but remains etched as home in KGPian nostalgia because it bears strong associations of untimely pangs of hunger and the tinkus and mohiles, of conversation and confidences, of hearts broken and jobs bagged. The reason for the sanctification of the teashop lies in the nourishment, conversation and camaraderie that the tea shop and its owner have offered to its regulars for years.

Like all neo-tribes, KGPians have also evolved an argot that may be deciphered only by the initiate. A mix of Hindi, English and Bangla, KGPianese is irreverently

\footnotetext{
21 “The place where you see his shop is not where it has always been. It has journeyed from RP crossing to where the STEP is presently and finally to where it is currently situated, and his shop was just a small thatched hut then, the only protection from the rains being the "imli ka jhaad" . Nitin Basant and Sandeep Rath. “An Institute Within an Institute”. The Scholar's Avenue. 18/8/05 Foundation Day Special
} 
ungrammatical, limited in vocabulary but remarkable in its combination of economy with precision. The same word may be employed in multiple contexts to elicit a range of associations and convey complex meanings shared by senders and receivers with the added advantage of being hidden to outsiders. KGPianese works as a code language providing access to the membership of the tribe, the right words acting as passwords for entering the select group of initiates who have secured admission the hallowed institution. With its specialized argot and rules of grammar, KGPian resembles language and plays the same role in forging identity as other languages do in identity formation.

Other than language, IITs have evolved rituals of belonging based on certain ways of carrying oneself, behaving and doing things. While these might strike outsiders as ridiculous, they signify special meanings to members. Most of these rituals are defined negatively in relation to other youth communities to conform to the image of a nerd that is won with great pride. Unlike members of other Indian youth subcultures, KGPians shun branded goods, 'cool' hairstyles and other indulgences sported by the 'liberal arts' types'. With mind as the dominant definer of identity, the body and its adornments are paid minimal attention. Good bodies and physiques are permitted to enter provided that they are complemented with an equally agile brain. To outsiders, KGPians seem awfully gauche but to themselves they appear as perfect specimens of humanity. They sincerely believe that good looks, social graces and finer aspects of life may be acquired in inverse proportion to intelligence. To belong, one must forget to speak correct English, affect a slouch and dress sloppily.

The most remarkable quality in this transnational diaspora is identification and loyalty to the institution. The mere mention of the magic password IIT suffices to gain access to a global IITian network. This sense of identification comes from the recognition that there is a distinctive IIT cultural ethos that creates a bonding between all those who have been part of the institution. In the process, the institution is sanctified by the same bonding through which nations are created. Though this identity is not seen as conflicting with national identity, IITs are like micro nations with their citizens, laws, landmarks and an official as well as unofficial anthem. An institution as a space that substitutes the space of 
the nation provides a new imagining of space and identity that puts into question the old relations between place and identity.

Since the IIT system was erected with the intention of supplying 'technical manpower for serving the needs of post-war development in the country', the IITs have become synonymous with academic excellence and their graduates accepted in the best universities of the world (Sircar, 1945). In the era of nation-building, there was deep concern about the large majority of IIT graduates leaving the country to pursue a higher degree and choosing to stay on. Policymakers alleged that IITs seemed to be serving the needs of research labs and corporations of the places of settlement rather than the needs of the Indian nation. However, with an increasing number of IIT alumni coming forward to help both the institutions they graduated from and the nation in various ways the charge of brain drain has been withdrawn and IITians have been roped into major national projects. While patriotism is a quality IITians do not lack, I believe that their affiliation to the institution overrides all other identity markers but can be accretive with other markers.

The three case studies discussed above bring out different aspects of what was perceived to be a homogenous 'Indian' diaspora. Despite having a common 'place of origin', they demonstrate considerable differences in the way they imagine home and relate to the nation and purity. Among the three, the Sikh imagining of home comes directly into conflict with that of the nation state for a number of reasons. As a colonial labour diaspora whose history predates the nation, 'the myth of return' for Sikhs must be propped either in the memory of a lost home in a Punjabi village or the dream of a homeland that did not exist at the time of departure. It is the centrality of shrines or places of worship in the Sikh imaginary rather than homeland shared with Hindu and Muslim Punjabis that facilitates the production of a transnational Sikh discourse converging on a virtual homeland. Home is similarly disengaged from nation in the Anglo-Indian selfimagining in which memory seeks refuge in the imperial history of a railway town, a missionary school, an army post and so on instead of the disorienting nation state. It is the IITian diaspora converging on a national institution to constitute a global network that 
originates in the myth of the nation. Whereas the Sikh and Anglo-Indian subjects are displaced by the nation state, the IITian is interpellated as the new citizen subject through a national institution and emerges as a global citizen. While the Sikh diaspora resolves the incompatibility between religious nationalism and modern nationalism in the production of a transnational identity narrative, the IITian diaspora disproves that nationalism is redundant in the new global formation. Similarly, the purity fetish that dominates Sikh self-definitions and Anglo-Indian ascriptions reveals the limitations of the celebratory postcolonial narratives of hybridity in non-metropolitan contexts. The diasporas construct the body as the privileged site for the contestation between the pure and the impure. The pure spiritual body of Sikhism implicates it in a sacral narrative, which intersects at some points with the Hindu miscegenation discourse that constituted the racialized Anglo-Indian body. It appears that only a new casteism of the mind propagated through the elite of the brain - the IITians - can release the bodies of the nation trapped in differences of caste, creed and colour to produce new forms of diaspora.

\section{Bibliography}

Appadurai, Arjun (1996) Modernity at Large: Cultural Dimensions of Globalization. Minneapolis: University of Minnesota Press.

Axel, Brian Keith (2002) The Nation's Tortured Body. Duke University Press.

Ashcroft, Bill, Gareth Griffiths and Helen Tiffin (2000) Key Concepts in Postcolonial Studies. London: Routledge.

Bahri, Deepika (2001) “The Digital Diaspora: South Asians in the New Pax Electronia”. in Makarand Paranjape (ed.) In Diaspora: Theories, Histories, Texts. New Delhi: Indialog Publications Pty Ltd, pp. 179-233.

Ballard, Roger (2003) "Panth, Kismet, Dharm te Qaum: Continuity and Change in Four Dimensions of Punjabi Religion”, in Pritam Singh \& Shinder Singh Thandi (eds.) Punjabi Identity in a Global Context. Delhi: Oxford University Press, pp 7-37.

Banga, Indu (1988) “Crisis of Sikh Politics”, in Joseph O’Connell, Milton Israel \& Willard G. Oxtoby (eds.) Sikh History and Religion in the 20th Century, Delhi: Manohar, pp 233-255.

Barrier, N.G. \& Verne A. Dusenbury (1989) The Sikh Diaspora: Migration and Experience Beyond Punjab. Columbia Mo: South Asia Books. 
Basant Nitin \& Sandeep Rath (1990) “An Institute Within an Institute”. The Scholars Avenue. Web address: http://scholarsavenue.blogspot.com/2005/08/18805foundation-day-special-institute.html (Accessed 2008).

Bhabha, Homi (1990) Nation and Narration. London: Routledge.

Bhagat, Chetan (2004) Five Point Someone: What Not to Do at IIT. Random House.

Bhaya Nair, Rukmini (1997) Technobrat. Delhi Harper Collins.

Carton, Adrian (2007) "Historicizing Hybridity and the Politics of Location : Three Early Colonial Indian Narratives”. Journal of Intercultural Studies 28(1): 143-155.

Chambers, Ian (1994) Migrancy, Culture Identity London: Routledge.

Clifford, James (1994) “Diasporas” in Cultural Anthropology 9(3): 202-38.

Cohen, Robin (1997) Global Diasporas: An Introduction, London: UCL Press.

Deb, Sandipan (2004) The IITians. Delhi: Penguin.

Dirlik, Arif (1997) The Postcolonial Aura: Third World Criticism in the Age of Global Capitalism. Boulder, Colo.: Westview Press.

Dusenbery, Verne (1995) “A Sikh Diaspora? Contested Identities and Constructed Realities" in Peter van der Veer (ed.) Nation and Migration. Philadelphia: University of Pennsylvania Press.

Gilroy, Paul (1981) The Black Atlantic. Austin: University of Texas Press.

Gupta Dipankar (1997) “The Sikh Imago”. The Context of Ethnicity: Sikh Identity in a Comparative Perspective. New Delhi: Oxford University Press.

IIT Foundation (nd) Accessed online at <www.iitfoundation.org/msgboard/showmsglist> (Viewed on $15^{\text {th }}$ December 2006).

Hall, Stuart (1993) "Cultural Identity and Diaspora”. Williams, Patrick \& Laura Chrisman (eds.) Colonial Discourse \& Postcolonial Theory: A Reader. Harvester Whaeatsheaf.

Jensen, Joan M. (1988) Passage from India: Asian Indian Immigrants in North America. New Haven and London: Yale University Press.

Kaur, Ravinder (1986) “Jat Sikhs: A Question of Identity” in Contributions to Indian Sociology 7 (20), pp. 221-239.

Lal, Vinay (nd) “The Indian Diaspora” in Manas: The Indian Diaspora. Accessed online at: <http://www.sscnet.ucla.edu/southasia/Diaspora/diaspora.html>.

Lal, Vinay (2001) "The Politics of History on the Internet: Cyber-Diasporic Hinduism and the North American Hindu Diaspora” in Makarand Paranjape (ed.) In Diaspora: Histories, Theories, Texts. New Delhi: Indialog Publications Pty Ltd.

Lessinger, Johanna (2003) "Indian Immigrants in the United States” in Bhikhu Parekh, Gurharpal Singh \& Steven Vertovec (eds.) Culture and Economy in the India Diaspora,. London: Routledge, pp. 165-222. 
McLeod, W H. (1989) "The First forty Years of Sikh Migration: Problems and Possible Solutions” in Barrier \& Dusenbury (eds.) The Sikh Diaspora.

McLeod, W H. (1999) Sikhs and Sikhism. Delhi: OUP.

Mills Megan (1996) “Some Comments on the Stereotypes of Anglo-Indians: Part 1". The International Journal of Anglo-Indian Studies. Vol (1)1.

Mishra, Sudesh (2006) Diaspora Criticism. Edinburgh, Edinburgh University Press.

Murali, Kanta (2003) “The IIT Story Issues and Concerns”. Oulook. Vol 20 (3): 1-14.

Nesbitt, Eleanor (1997) "Splashed with Goodness": The Many Meanings of Amrit for Young British Sikhs in Journal of Contemporary Religion. Vol 12 (1).

(2000) The Religious Lives of Sikh Children: a Coventry-Based Study. Leeds: Community Religions Project, University of Leeds.

(2004) "I am a Gujarati Lohana and a Vaishnav as Well: Religious Identity Formation among Young Coventrian Punjabis and Gujaratis" in Coleman, S and Collins, P. (eds.) Religion, Identity and Change: Perspectives on Global Transformations. Aldershot: Ashgate, pp 174-90.

(2005) "Young British Sikhs and Religious Devotion" in King, Anne S \& Brockington, John (eds.) The Intimate Others: Love Divine in Indic Religions. New Delhi: Orient Longman, pp 310-36.

(1997) “We are all Equals: Young British Punjabis' and Gujaratis' Perceptions of Caste”" in Journal of Contemporary Religion, 12(1): 17-33.

Oberoi, Harjot (1994) The Construction of Religious Boundaries: Culture, Identity and Diversity in the Sikh Tradition. Delhi: OUP.

Pettigrew, Joyce (1997) “The Jats of Punjab” In Gupta The Context of Ethnicity: Sikh Identity in a Comparative Perspective. New Delhi: Oxford University Press, pp. 163-175.

Sheffer, Gabriel (ed.) (1986) Modern Diasporas in International Politics, London and Sydney: Croom Helm.

Safran William (1993) "Diasporas in Modern Societies: Myths of Homeland and Return”, Diaspora 1(1):83-93.

Sarker et. al. (1951) "Development of Higher Technical Institutions in India - Report of Sarker Committee.” Central Bureau of Education India. March 1948. Reprint. Manager Government of India Press Simla.

Shuval, Judith T. (2000) "Diaspora Migration: Definitional Ambiguities and a Theoretical Paradigm”. International Migration, 38 (5): 41-57.

Sukhatme, S P. (1993) The Real Brain Drain. Delhi: Orient Longman.

Van der Veer, Peter (1995) Nation and Migration. The Politics of Space in the South Asian Diaspora. Philadelphia: Philadelphia University Press.

Vertovec, Steven (1999) “Three Meanings of Diaspora: Exemplified among South Asian Religions”. Diaspora 7(2). 
Braziel, Jana Evans \& Anita Mannur (2003) Theorizing Diaspora: A Reader. Oxford: Blackwell Publishing.

Films and websites

Article 366(2). "Constitution of India/Part XIX”, in Wikisource. $<$ http://en.wikisource.org/wiki/Constitution_of_India/Part_XIX>, (Viewed on 27.1.2008).

The

$$
\text { India }
$$

Travel

Forum,

Accessed

online

at: $<$ www.indiamike.com/india/archive/index.php/> (Viewed on $15^{\text {th }}$ December 2006).

K S Sethumadhavan. Julie, 1975

Sen Aparna. 36 Chowringhee Lane, 1981 